\title{
ANNUAL REPORT FOR THE YEAR ENDING 31st DECEMBER, 1959.
}

\section{Presented by the Council to the Annual General Meeting, 26th April, 1960.}

Vice-Presidents.-During 1959 the Society suffered a very great loss in the death of Dr. Willard Van Name.

Meetings of the Society.-The Annual General Meeting and two other General Meetings were held. Council met four times.

The Journal.-The usual three issues of Oryx were published.

Films.-The Society's films, a list of which is published in every issue of Oryx, have been well used, especially during the winter months.

Lectures.-Talks on the Society's work, illustrated by slides or films, were given at the Royal Commonwealth Society, at the British Museum (Natural History), at other societies and to schools.

Kindred Organizations.-During the year the Society kept in close touch with kindred societies throughout the world. The Secretary represented the Society at the international conference on Oil Pollution of the Sea held in Copenhagen in June.

Membership.-During the year the Society increased by 348, nearly one a day, to 1,799 members. This splendid increase is due, to a considerable extent, to the interest aroused in wild life preservation by "Operation Noah".

Deeds of Covenant.-The long argument with the Inland Revenue was decided in favour of the Society and the refund of tax recoverable under deeds of covenant over the last three years has been claimed.

Accounts.-Again the Society has to report an excess of expenditure over income, but against a deficiency of $£ 15311 s$.

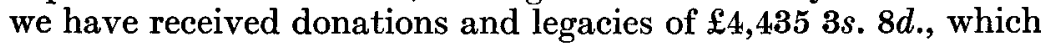
has been credited to the General Reserve Fund. This amount includes the legacy of $£ 4,000$ from our great benefactor, Dr. Willard G. Van Name, upon whose past generosity the Society has so very largely depended. Council asks other members also to remember the Society when making their wills.

Although, as the audit shows, the finances of the Society are sound, a great expansion of work is contemplated in 1960 and for this money is urgently needed.

Operation Noah.-The Society's effort for Operation Noah started at the press conference on 19th March, when a public appeal was launched for $£ 10,000$ to help the rescue work already 
begun by the Game Preservation and Hunting Association of Northern Rhodesia. On 19th August, exactly five months after the appeal was opened, a total of $£ 10,000$ was reached and advertisement was stopped. Little advertisement had in fact been necessary for the Press itself took up Operation Noah as news and continued to do so up to and beyond the end of 1959 . But though the expenses were small, the amount of office work was heavy, especially after 22nd August when Mrs. Rosemary Russell, who had been employed for Operation Noah, ceased her work. But although advertisement had ceased, correspondence and the inflow of money continued.

From September to December the whole clerical and accounting burden of Operation Noah fell upon the Society's Assistant Secretary, Miss Kathleen Clarke, and the Council wish to express their special appreciation of the work she accomplished during those four months.

The audited receipts and expenditure account of the Kariba Fund, which is presented with this report, shows that up to the end of $1959, £ 11,45116 s$. 1d. was subscribed to Operation Noah. Of this amount $\mathfrak{1 0 , 5 0 0}$ was sent to Northern Rhodesia and $\$ 44216 s$. $4 d$. remained in hand at the end of the year. The expenses of this Fund amounted to $£ 508$ 19s. 8d., less than $4 \frac{1}{2}$ per cent of the sum collected.

As a direct result of subscriptions through our Society, the rescue ship Erica was built and has entered into service. Her chief function will be that of a parent ship from which rescue boats can operate, but a large space aft has been specially prepared for rescued animals.

The Survival Service Commission.--In June the Society undertook the work of the Survival Service Commission of the International Union for Conservation of Nature and opened an extra office, both for the Survival Service work and for the ever-increasing work of the Society. A grant at the rate of $\mathfrak{2 5 0}$ a year towards the expenses connected with the Survival Service was received from the Union. During the year the Service investigated the present status, the degree of protection given and the prospect of survival of the animals believed to be in greatest danger of extermination throughout the world.

A special investigation was started into the position of the African black rhinoceros-about which alarming reports had been received from many places-to consider whether this rhinoceros should be regarded as an endangered species and special efforts made for its preservation. The three Asiatic rhinoceroses were already on the list of endangered animals. 
Acknowledgments.-The Council expresses the Society's thanks to Mr. L. P. Warland for his fine photograph of the red lechwe, the subject of the 1959 Christmas card.

Thanks are offered also to those who gave lectures and showed films at General Meetings.

The Society is most grateful to the Zoological Society of London for office accommodation and for the unstinted help given by that Society's staff throughout the year. 